\title{
Redefining the Way Theatre is Created and Performed: The Radical Inclusion of Suzan-Lori Parks's 365 Days/365 Plays
}

\section{Philip C. Kolin}

Suzan-Lori Parks, the first African American woman to win the Pulitzer Prize for drama (Topdog/Underdog in 2002), has with 365 Days/365 Plays challenged and redefined the way theatre is created, produced, performed, and even interpreted. Not fearing to enter dragon country, Parks decided a few years ago to write a play each day for an entire year. On 13 November 2002 she started and by 12 November 2003 she had finished her phenomenal journey. "It [was] about being present and being committed to the artistic process every single day, regardless of "weather." She further claimed, "You can't write a play a day for a whole year without practicing radical inclusion, where every idea that comes to the door of your creative mind is welcome. You can't have a bouncer at the door saying, 'You and you, but not you.'"' Her ambitious and radical collection of 365 plays would boggle the mind's eye of any playwright, producer, director, or critic. But her indefatigable self-discipline was matched by an unstoppable resolve to have these plays staged nationwide. Enter Bonnie Metzgar, Parks's longtime friend, the Associate Artistic Director of Denver's Curious Theatre, and, for eight years, the Associate Producer of the Public Theater under George C. Wolfe. Parks had put the 365 plays away in a drawer for a few years, but in 2005 Metzgar convinced her that they needed to be performed, and on a scale so large it brooks no comparison in national theatre history, or world theatre annals for that matter.

Parks and Metzgar created the 365 Days/365 Plays National Festival, a project divided into a network (or hub) of at first 7 and then 15 cities or regions across the United States, including the Northeast, New York, Atlanta, the Carolinas, Mississippi river towns, Minneapolis, Chicago, Austin, Greater Texas including San Antonio, Denver, Los Angeles, San Francisco, Seattle, and Washington, D.C.. Each hub was coordinated by a satellite theatre or a council (seven coordinating theatres in Chicago) that then enlisted up to 52 theatres or performance groups in each hub to stage a week's worth of 365 . Satellite theatres include the Alliance in Atlanta, the Guthrie in Minneapolis, and Center Theatre in Los Angeles. Between 16 November 2006 and 15 November 2007, Parks's marathon collection was simultaneously performed week by week ( 7 plays) by more than 800 groups, each according to its own interpretation and resources. As long as a theatre did a week in the order in which the plays were written, it could choose how the plays were done (read or staged in full costume or not), where, and when. For instance, a theatre 
might stage its seven plays all on one night, or over two or three nights, or perform a play each night for a week, or could even repeat play(s) on the same day(s).

As a theatre in each hub finished its week of plays, it then passed 365 along to the next theatre that staged the following week, amounting to an unprecedented Olympiad of Theatre. In fact, Parks's 365 has been rightfully termed the "largest American theatre collaboration ever."' The result is a series of running cycles of the 365 plays as each hub, or network, completes an entire year. Every hub, of course, exists within the larger constellation of the nationwide 365 Festival. The popularity of 365 spread so fast and so far that, according to Metzger, "We do not even know how many theatres are doing the 365 plays." 4 As Damaso Reyes accurately put it, "For the first time, theatres across the continent will be working together to produce the work of one playwright, bringing together disparate parts of a far-flung and often disconnected artistic community." In all probability, Parks has surpassed any other playwright, including Tennessee Williams and possibly Shakespeare, in having his/her works produced across the U.S in 2006-2007.

The variety of troupes doing 365 is staggering. It has been performed by small amateur groups with limited resources and time (e.g., an hour rehearsal before performance), by summer stock companies, and by institutional theatres with stateof-the-art technical resources. 365 has been part of a mainstream season and also used as a curtain-raiser. An all-female ensemble - Women's Will_-did Week Two of 365 in Berkeley. ${ }^{6} 365$ has also been widely performed at campus theatres and in college dorms and by a plethora of small theatre/performance groups across the country. 365 can be done in any language or dialect, too. Audiences at performances done by La Colectiva in San Antonio or the Latino Theatre Company in Los Angeles have experienced Parks's works done with a Hispanic accent. Chicagoans could hear 365 performed in a "mix of Spanish and English at multiple sites" by Teatro Vista or enjoy 365 interpreted by the city's leading African American ensemble, Congo Square Theatre Company. ${ }^{7}$ But, as Shannon Richey at the Zachary Scott Theater in Austin cautions, it is crucial to remember "You do not have to be a 'theater' to produce a week of plays." 365 is also a draw at bars, such as Webster's Wine Barn in Chicago's Lincoln Park where patrons can see a play and catch other spirited harlequinades. Serendipitously, Parks's first play, "Betting on the Dust Commander" (1987), opened in a sleazy bar called The Gas Station, on Manhattan's Lower East Side where lighting changes were made by plugging and unplugging an extension cord. ${ }^{9} 365$ has also been performed at hospitals, nursing homes, churches, museums, middle and high schools, and even at personal residences. In fact, independent artists can apply to stage the plays.

365 is panoptic. It has its own national web site (http://www.365days365plays.

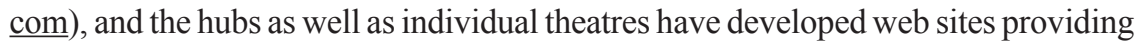
schedules and blogs describing performances, as coordinator Danielle Mindess insightfully has done at Emory University for the Atlanta hub. Moreover, according 
to Rebecca Rugg, "Each school will post a video document of their performance where there will also be an opportunity for audiences and participants to discuss the productions." ${ }^{\prime 10}$ The plays have prompted numerous directors, including Steven Westdahl at Collective Works in Atlanta, to create "videos for each of the plays ... rang[ing] from realistic film work . . to animated shorts." ${ }^{11}$ Inescapably, numerous recorded performances of 365 are loaded onto iPods across the country. Video footage has also played a part in several productions which incorporated film into their interpretation of a play, as Kathy Hilton and Company did. ${ }^{12} 365$ has also spawned art based on the plays with original compositions adorning walls of several make-shift playhouses. With 365 Parks and Metzgar have created a Rubik's Cube of theatre. It is not coincidental that Parks is a long distance runner, ${ }^{13}$ victorious in ultra marathons, whether they are races or writing plays.

Undeniably, the grassroots ethos at the heart of 365 is changing the way theatre is done. Parks and Metzgar have deconstructed some hallowed traditions as they launched their crusade to transform attitudes toward theatre. The first sacred cow put out to pasture by 365 is that a theatre has to compete for the distinction of presenting a national/world premiere. Parks and Metzgar have assaulted the venerable and privileged status guarded by prominent institutional and regional theatres. Because of 365 hundreds of worldwide premieres have occurred as each of the 52 theatres in every hub can debut a week of Parks's plays. In the spirit of 365 , storefront theatres as well as more established ones each have an equal share in claiming a premiere. The title of Randy Gener's review of 365 in American Theatre is apropos - "One Nation, Under Suzan-Lori Parks." ${ }^{14}$ In fact, Parks rejected the idea of a major theatre such as the Public in New York garnering the singular honor of premiering the entire 365. As the driving force behind production, Metzgar similarly eschewed exclusivity: "We are trying to dispel the thought that the Public Theater is somehow doing anything more important than anyone else. . . They are one of 52 theatres in New York, the same as there are 52 in Atlanta and 52 in Colorado." ${ }^{15}$ Egalitarian to the core, Parks and Metzgar have also put their beliefs where the money isn't. Theatres/groups are prohibited from charging admission to performances of 365 , and Parks herself is to receive only a $\$ 1.00$ licensing fee for each play performed, a practice she terms "negative money." 16 Actors in 365 , too, have performed without payment, though theatres can (and do) voluntarily pass the hat. Not since the days when Greek citizens enjoyed free plays, bringing all Mycenaean society together, have audiences received so much entertainment bang without a buck.

Shooting down another tradition, 365 democratizes theatres by linking them locally and nationally. The spirit of communal theatre is at the heart of 365 . It's as if Parks were energizing Arthur O. Lovejoy's trope of "plentitude" "17 — whatever 365 plays exist can and will be performed by any theatre/troupe/individual wanting to stage/read them. Productions everywhere count. All theatres are part of - and 
hence interconnected to - each other, the "larger community of theatre," according to the Festival website. ${ }^{18}$ As Mace Archer, the Director of the Billings, Montana, Venture Theatre happily admits, “Until now I don't think a theater in Montana has produced a word of Suzan-Lori Parks. It feels separate here. The connectivity (offered by ' 365 ') is important to keeping us aesthetically alive." ${ }^{19}$ Miriam Leal, Cofounder of La Colectiva, also lauds 365 as a vehicle for building community: "If we could have [the Rio Grande Valley theatre troupes] come here and have a new voice here and then go down there and share our voice, it gives a different location and different ideas. You meet new people and do some networking." ${ }^{20}$ Joseph Roach sums up Parks's iconoclastic inclusiveness well_- "She is making plays available in a way not conventionally imaged in theatre." 21

Countering another conventional idea-regarding theatre as privileged, protected, and even separate space - the Festival insists that theatre can and should be everywhere. 365 magnificently thrives in any theatrical landscape - traditional or nontraditional, lavish or liminal, indoors or outdoors, in intimate black box grottoes or on thrust and main stages. Reporting on the productions in the Seattle hub, Brendan Kiley observes that the 365 plays have been performed at the "venerable" Intiman Theatre but also at coffee houses, and "producers are talking about staging the plays in ice rinks, libraries, and the water tower in Volunteer Park. The Seattle Rep might do 'Impala' [one of the plays] which features a Chevy Impala, in its parking lot." 22 In Denver, the Curious Theater Company mounted a peripatetic production when

[a] swollen crowd exceeding 150 showed up not knowing what to expect or where to go. They followed the short stories unfolding around them starting on the sidewalk across the street, onto the theater steps and inside to the lobby, stairs and balcony. This created a walking-tour effect, as crowds wandered from one play to the next while standing around and among the actual performances. Upon completion, each play simply started again. $^{23}$

Similarly, at Chicago's Moving Dock Theatre Company, "hallways, lobbies, stairwells, and studios of the landmark Fine Arts Building became part of the event." 24

As hundreds of productions prove, 365 works effectively outdoors. As part of Looptopia, “American's first dawn to dusk cultural celebration in downtown Chicago, the Goodman Theatre staged 365 in the theatre's public spaces, or areas not normally used for performance." ${ }^{25}$ In Austin, as Metzgar pointed out, a troupe "had a string quartet for the play 'Here Comes the Messenger.' And they did it on a pedestrian bridge, with 365 balloons tied to the bridge." ${ }^{26}$ Dave Steakley, who 
produced Week One in the Austin hub, declared, "it would be great to have an actor in a little canoe having to interact with an actor who's on the bridge." ${ }^{27}$ Lisa Paulsen, Director of the Emory Playwrighting Center, opined, "I'm really looking forward to seeing theater in an art gallery, at MARTA stations in February, and read in front of the AIDS Quilt at Inman Park Festival." ${ }^{28}$

365 encourages almost as many production styles as it does playing spaces. As Mark Blankenship claims, "It stands to reason that [each theatre] will have insights to share," and responses to any one play can and should vary, radically. ${ }^{29}$ In the first 365 play, "Start Here," the character Krishna accompanies a soul Arjuna on its journey from life to death, or is it death to life? At Yale University the play was done kinesthetically where a shadow figure stood silently behind each of the two Hindi characters, pulling him/her back as she/he advanced toward an escape to the audience. At the Music Center plaza in Los Angeles, actor Patrick Breen dressed as Krishna. ${ }^{30}$ The Public Theater, on the other hand, did the play minimally "in the style of a . . cabaret. Curtains on strings swished back and forth; an accompanist plunked away at a visible piano and actors stepped up to read stage directions." ${ }^{31}$ Incorporating the agit-prop zeal of the 1930s, with its improvisational acting and politically charged motivation, the New Haven [Connecticut] Theatre Company performed its week, near Christmas, at an "unconventional location, about 30 steps from the upscale apparel shop Ann Taylor Loft, [which] was a clever way to reach the public during the busiest shopping season of the year." ${ }^{32}$ Actors posed as fellow shoppers. 365 has also been done as a happening. "One group [drove] around New York in a van, performing plays in random locations" while the cast of Fools Fury

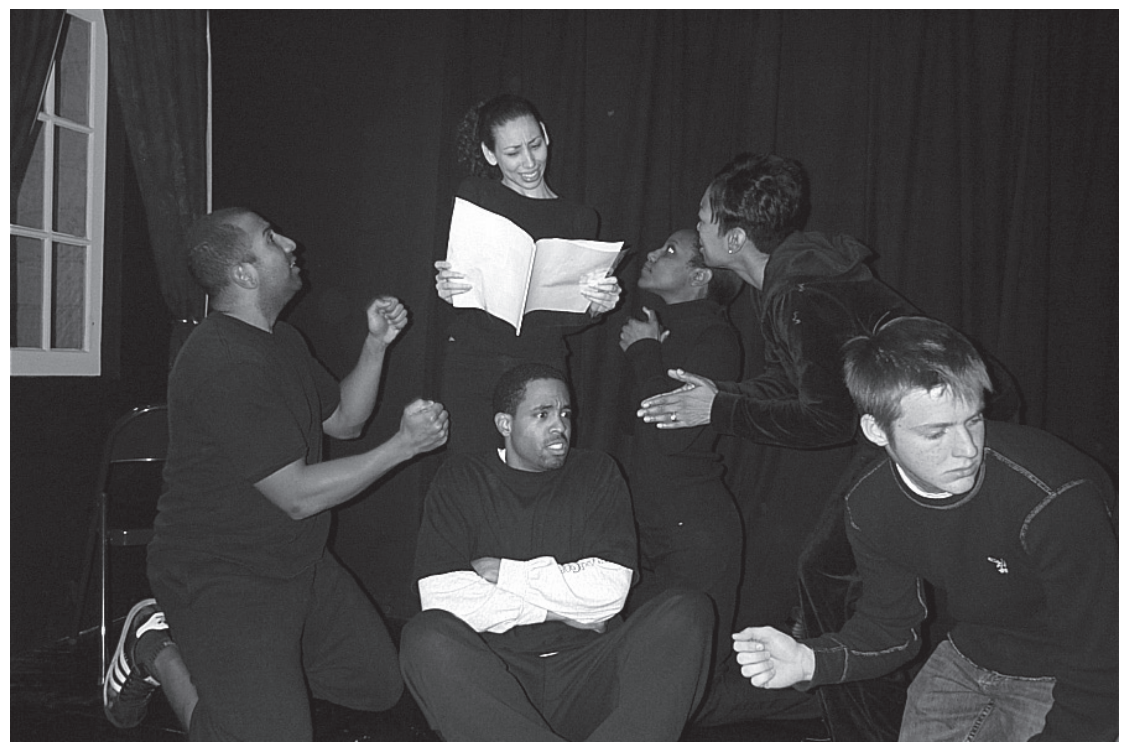

The Company Acting Studio, Atlanta GA:

"The Day After the Presidents Day Sale" 365 Days/365 Plays, February 12-18, 2007. 
in San Francisco spent "their days jumping in and out of cars, performing plays in public spaces like Union Square and Yerba Buena Gardens. ${ }^{\prime 33}$ Reminiscent of revolutionary theatre, Colorado's Wrecking Ball did "its portion of the plays (28 May-3 June) in [confrontational] guerrilla style [theatre] at popular Boulder hangouts such as the Boulder Creek Path or Chautauqua's Royal Arch Trail." ${ }^{134}$ Odyssey Productions in Seattle also did its share of 365 as "site-specific guerilla theater." ${ }^{35}$ Given the diversity of playing places and styles, the many representations of a 365 premiere have ensured and promoted the pluralistic complementarity. Parks and Metzgar have made the text of 365 totally accessible to directors/actors just as they have to the public.

Parks's reasons for embarking on her 365 odyssey reveal, as perhaps never before, the ontology of an artist's creative process. Parks (40 when she began 365), a MacArthur Foundation Award genius, approaches reality in profound ways as writer and social advocate, focusing on identity, race, gender, politics, wars, history, social class, myth, and, as always in her work, a sense of humor. 365 gives us an opportunity for an affective engagement with her operational style. Described as "zany, gregarious, a natural born organizer," Parks herself readily admits that doing the 365 project was "an incredible obsessive, crazy thing to do, ${ }^{36}$ a window into her psyche. 365 hand-leads audiences into her cerebral/textual space(s). It's as if 365 is a series of mass mediated circuits through and over which we overhear conversations in her mind. Insistently, though, she rejects any comparison between writing 365 and keeping a diary, arguing that, unlike a diary, the plays were meant to be shared. But as Metzger, her friend, director, and production collaborator, claimed: "Suzan-Lori Parks has turned intimacy . . . outward." ${ }^{37}$ The plays reveal Parks's inner and outer worlds simultaneously. Ineluctably, for Parks 365 is an ongoing ritual celebrating the vibrancy and reciprocity of her creativity - her chi, if you will, the essential life force of her being. As she explained, "Doing something positive can make something positive happen." ${ }^{38}$ On one level, then, 365 might be Parks's biotext, the celebration of her identity as artist/thinker.

Undeniably, 365 emerges from a powerful spiritual belief at the core of Parks's creativity. A student of yoga and ancient religions, Parks injects a decidedly Hindu mysticism throughout her year-long cycle. Both she and Metzgar describe this mysticism, or flowing energy, as the "the River of Spirit that guided us." ${ }^{39}$ Using another (though more precipitous) water image, Randy Gener graphically described the vigor and violence of 365 as Parks's "love tsunami of theatre. ${ }^{\prime 40}$ The distinctive Sanskrit mantra tattooed/inscribed twice around Parks's forearm-"Follow God, the Inner Spiritual Guide" - can be taken as her creed for 365. According to Parks, the Spirit led her to write a play a day, which, of course, is consistent with her view of theatre as church. The plays, she maintains, became "her daily offering to theatre;" "41 they were "like a prayer." ${ }^{42}$ Symbolically, one of the last works in 365 is entitled "Puja Play for Sri Ganesha," a puja being an extended Hindu daily prayer. 
Moreover, quite a few plays suggest the eschatological-e.g., "The Ends of the Earth," "3 Lives," "The Search," and "God's Eye is on the Sparrow." As Danielle Mindess puts it, "Parks's book [of plays] is like a daily devotional of plays. I can read it, decide which shows I want to see, then go down to the appropriate venue." 43

Parks's Hindu spirituality gives audiences a feeling that they are watching the excavation of souls, their transformation, reincarnation, and return in a seamlessly endless cycle. For example, "A Play for the Day of the Dead" starts November because, as Parks professes, "The ones we love are always around." "A Person of Great Compassion is resurrected from the dead" in "A Play Written on a Piece of Parking Paper." In "Ajax Big and Little," the dead are very much present eating enormous meals and "during the tail end of history ... get noisier with each passing year." ${ }^{4}$ Labeling 365 a "yoga play," C. Denby Swanson offers convincing reasons why: "What's happening ... around the country is large-scale yoga drama: breathing together, observing together, giving attention," 45 the connectivity of artist, theatre, actor, audience, and script. A character in "The Key," humorously but nonetheless profoundly, confesses that "My day has been totally transformed," the state toward which, ideally, 365 should move directors, actors, and audiences for Metzgar and Parks. Critics may be a tougher audience. The two-line play "The Line to Life" plunges audiences into the heady ether of mystery: the first character confidently asserts, "The line of life is long" while the second, called Someone Else, rejoins: "But the lifeline is short." Perhaps most powerfully reflecting Parks's Hindu-inspired spiritual outlook, "The Sea, the Sea" contrasts a harried character worried about his identity/fate ("What if I cannot be what I want to be") with an implacable guru who answers with resignation, "Then you'll be someone else." After being immersed in 365 , actors and audiences may both be "someone else," or at least be open to seeing others and themselves as being transformed.

While floating down a spiritual river of Hindu energy, the 365 plays are also, most certainly, connected to American literary legacies, as are many of Parks's other works. Her earlier plays, In the Blood (1999) and Fucking A (2000), have been highly prized for their radical deconstruction of a white literary icon, The Scarlet Letter, recasting Hawthorne's Hester Prynne as a street-smart, procreative, tradition-defying African American mother, also named Hester. Parks's wry capsule summaries of the plays, presented at the end of 365 Days/365 Plays, might handily be juxtaposed against the sardonic quips of humorist Mark Twain and conveyed through his authorial-sounding persona in Huckleberry Finn or Pudd'nhead Wilson's Calendar. Connected to still another American classic, Parks adapted Zora Neale eHurston's Their Eyes Were Watching God in 2005 for Oprah Winfrey Presents. To be sure as well, a fair share of the 365 plays sizzle like Albee's comic and savage assaults on the American family/dream. Others keep company with David Mamet's urban, fast-take scripts with their stichomythic dialogues peppered with tough-guy talk ("Impala"; "Pussy") and twirling con games (e.g., "Babe Catcher," 
where a man with a scythe convinces a troll to dig up a pot of hidden gold for this aphrodisiacal grass cutter). Like both Albee and Mamet, 365 serves audiences a shock tonic for their cultural amnesia, especially their ignorance of (African) American history and myth.

Even more telling, however, are the ways in which 365 is Whitmanesque - in its vision, provocative sexual/spiritual imagery, and streaming catalogues of quotidian life. If Parks has a poetic forebear in advocating radical inclusiveness, it is Whitman. Her Sanskrit mantra and Hindu spirit are consistent with his paean to democratic vistas. Like Whitman, Parks celebrates a vision of diversity and eternal recycling energy. Just as he declared in "Song of Myself" that every atom that belonged to him belonged to his readers, Parks has made her "atoms" (the 365 plays) openly, freely available to theatres, directors, actors, and audiences. Matt Wrather, whose New Haven Theatre Company did a week of 365, could have been speaking as much about Whitman as about Parks: "We're about letting people in, not keeping them out. We're about redefining the traditional ways of doing things." 46 Powerful, self-identifying iconography also links Parks to Whitman. While the first edition of Leaves of Grass carried no by-line, it did present an emblematic portrait of the bohemian, communal-minded Whitman on the cover, symbolizing an emerging American democratic self. 365 Days/365 Plays also shows an iconic representation of Parks on the cover in a series of photographic frames where she is seated in a red Mustang convertible, offering a Whitmanesque invitation to discover and transverse an even more pluralistic America. 365 in fact might even be regarded as a postmodern African American woman's "Song of Myself," performed on the national stage.

Above all, though, the 365 plays reside in paradox. They flee from mainstream theatre yet they are tied to it as well. They project a feeling of urgency but preserve the desire for the eternal. They fly through yet stabilize the evanescence of performance. 365 comprises very different short plays with a running time of two to three minutes up to 10 minutes. Some of them could "fit on a post-it note" 47 while others stretch like miniature epics to five or six pages. But, of course, length is no sure or easy determiner of what 365 is. Each play is its own world. ${ }^{48}$ So much happens in these plays, and so little. Seven of them can be performed in just one hour, yet audiences often have the feeling they have traveled to the distant corners of time, space, and galactic thought. As Erika Rundle, the dramaturg for the Mt. Holyoke (Parks's alma mater) 365, stressed: "Even though each play is short, the same artistic and technical elements required for a full-length play are needed." ${ }^{49}$ Some 365 titles read like a much longer play with a beginning, middle, and end. The two-page "Sin Collector" is even divided into 3 scenes. Yet at least half a dozen of the plays consist only of stage directions - e.g., "Does it Matter What You Do?," "4 Directions," or "Talkback." Numerous plays are monologues while in others "a throng" of people or a "horde" ${ }^{" 50}$ rush through. Parks herself described 
365 as "snapshot plays but mythic at the same time. They're operas." ${ }^{51}$ Myths and operas all in a snapshot frame - this is indeed a fittingly paradoxical assessment of the plurality of lengths, styles, dramatic techniques, and genres that collectively flock under 365.

An even more productive assessment of 365 comes from Parks, who terms the cycle a "black play," or "plays that cross boundaries." 52 Elsewhere she describes a "black play" as one where "everyone is invited to the table." ${ }^{\prime 53}$ As a black play, then, 365 is both radical and inclusive - personal and universal, organic and holistic, all at once. Contributing to a special issue of Theatre Journal on "Black Performance," Parks catalogued the qualifications/features of what a black play is (or is not) under the title of "New Black Math." ${ }^{54}$ Many of her descriptions articulate and advance the criteria by which audiences and critics might approach and appreciate 365 . From Parks's seven-page catalogue, I pair a few of her illustrative contraries to reveal the paradoxical qualities of a black play. It "is mixed," claimed Parks, "buck wild," and "takes you to the bridge." "A black play is angry" but it also "got style" and "is deep." "A black play is of the people by the people and for the people." A "black play" is "old" and "just getting started"; it "might set the race back ten years" yet "wants to uplift the race" at the same time; it is "tragic" and "funny as hell"; "the Glass Menagerie" is a black play and it is also the place where "Mr. Baldwin makes his home." It is "a white play when the lights go out" and "a white play when you read between the lines." "A black play is running for president" but also "got its picture on the wall of your local post office." "It embraces the infinite." Reflecting this crucial attribute of a black play, 365 shows that Parks has often dared the impossible. For instance, in "A Piece of Packing Paper," "a director walks on the water, across a swimming pool" and in "Father Comes Home, Part 11," "the action repeats eternally." ${ }^{55}$ Most relevant of all, a "black play is coming soon to a theatre near you," just as Parks's 365 cycle has done!

Undoubtedly, 365 has compelled directors, audiences, and critics to rethink what a one-act play is. Parks's year-long cycle is genre-defying. She has radicalized the idea of a one-act play as modeled on Pirandello, Chekhov, Genet, Williams, or Albee with its (re)configuration of characters, plots, and action. Instead, 365 undermines these formal constituents and in the process challenges theatre-makers' and theatre-goers' expectations about performance and language. 365 packs a wallop into a half page of dialogue that equals - in some instances, surpasses - the existential awakenings in a 10-page one-act by Sartre or Albee. Parks needs neither character nor plot to create a sustaining "one day play" in the life of theatre. Surely character is no determiner, post-Parks, of a one act, for 365 contains plays with no or two characters as well as multitudes of them. Parks's language in 365 is poetic and stark all at once. These plays might even be compared to short prose poems or one-paragraph short stories. Parks's half-page plays are, in fact, closer in format to a prose poem than a traditional one-act play. As we saw, some 365 plays are, 
exclusively, stage directions, leading us away from spoken theatre into mime or studio art. Parks's hallmark "spells," or elongated "rests" signaling that her "figures experience their pure true simple state," silences, and some are even comparable to Beckett's experiment in Breathless. Her greatest contribution in these snapshot operas, though, may be the wedding of Beckettian sacramental terseness with Brechtian-like epic theatre, all in a page or two, or under. 365 pushes theatre to the limits of definition/precedent.

The variations on/radicalizations of genres in 365 take audiences to that liminal world, poised between the stage conventions that 365 evokes and revokes simultaneously. 365 includes bagatelles ("A Flip-Off Flip Book"; "Kissing Booth") and hilarious farces ranging from a man urinating on his car ("Impala") to a woman running up to a man and licking his chest ("Lickety Split") to actors crawling across a stage in "A Search for the Meaning of Life." Pasquinades poke their way into 365 as well, including "Watergate," Hollywood bio-pics, "Vote Booth," and national festivals ("Photos With Santa," "Presidents Day Sales," "Presidents Puppets"). In "House of Cards," a woman concludes, "There's no winning in this country." Some plays swing with gallows humor/jibes but then turn deadly philosophical as in "The Executioner's Daughter" where a condemned prisoner learns that the hooded punisher is her mother or in "Veuve Clicquot" where a snooty condemned man orders a fancy bottle of champagne with his last meal and tells the waiter, who claims he'll miss the convict's humor, "Maybe missing is only something we do when we're alive." Some plays read like spoofs on, or urban versions of, folktales such as the "Mason Jar Genie" where a black man genie terrorizes a white master" or "The Legend of Wiglefortus" that mocks a crucified prince, a bearded daughter, and a wicked king. A torch-song-addicted dragon pines in "Dragon Song."

True to Parks's own pronouncement, 365 offers opera-like compositions, including "Chamber Music" and "Scatter (A Musical Melodrama)." Certainly, Parks's technique is in some plays indebted to jazz with its improvisation and repetition. In several plays, songs, especially the Carter Family (e.g., "Coney Island Joe's"), are essential to performance. For many directors, such as Laurel Ollstein, from the Los Angeles Playwright's Arena, music became an inspiration for production of her own spirited interpretation of Week 3:

We took each piece in its own world and used the music and the space to tie them together. . . Jon Rivera had suggested using the chapel at the Lutheran Church . . . a beautiful little old church with wooden pews and stained glass and best of all a fabulous old pipe organ. We got the church organist involved with the production. ... The organist and I worked out pieces that he could play between each of the 7 plays along with a closing number. I staged the event using every corner of the 
chapel-the commitment from everyone was fantastic. ... We used the church lighting - along with 100 candles that were lit during the performance. It was a magical night and it didn't feel minimal at all. ${ }^{58}$

Besides plays with or about music, 365 contains postmodern eulogies for many musicians and artists - "the lives of people who died the day I wrote the play," as Parks admits. ${ }^{59}$ There are upbeat dirges for Barry White, Johnny Cash, Nina Simone and Celia Cruz, Gregory Hines, and Carol Shields, but a hilarious send-off for a smug George Plimpton and a jealous John Ritter, both dying on the same day. In Parks's land of the lotus-sucking dead, Plimpton dismisses the sitcom star with these words: "Maybe she'll put you in my play. I'm probably better known but - perhaps she'll put you in - parenthetically." Also among 365 's mutating genres are variations of Shakespearean tragedy ("Hamlet"/"The Hamlet" and "Project Macbeth"), modern classics ("Blackbird [Sea Gull]"), (bawdy) adaptations of Greek myths (Oedipus in "The Original Motherfucker") and other

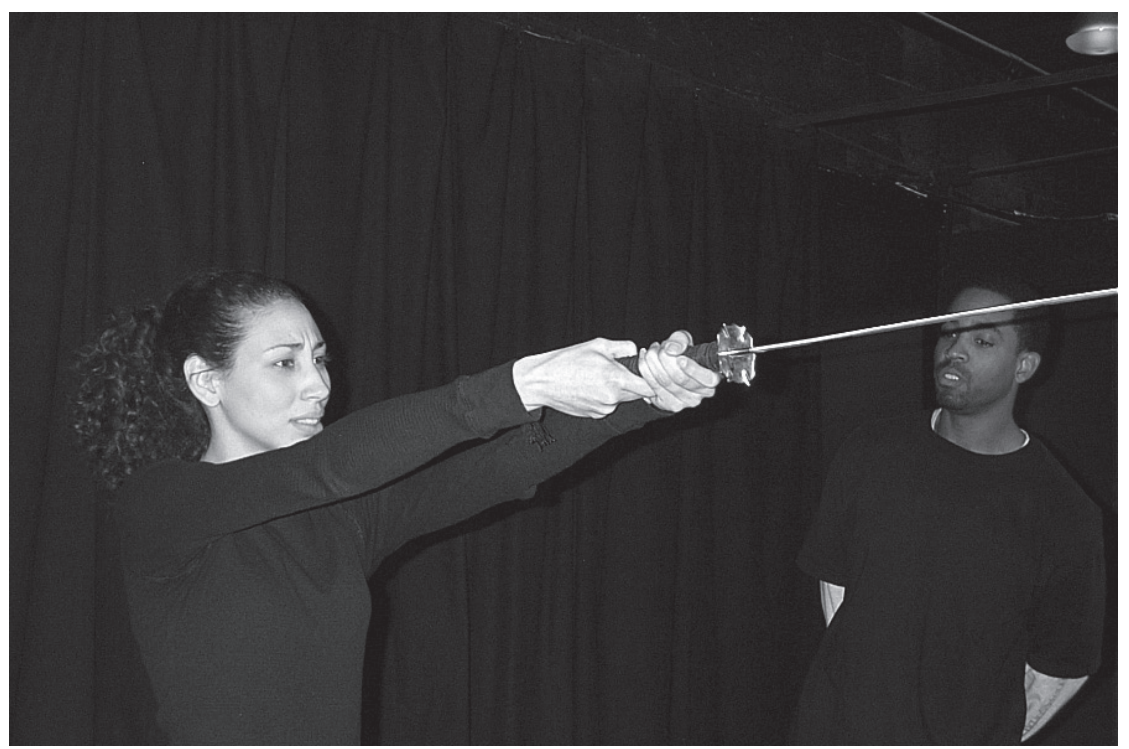

The Company Acting Studio, Atlanta GA: “(Again) The Butcher's Daughter (For Bonnie)" 365 Days/365 Plays, February 12-18, 2007.

classical figures - Tantalus, Cassandra, and Clytemnestra on television (in "Greek Tragedy \& Jerry Springer”). Always a punster, Parks's “A Yarn from the Skein of (Un)Happiness" introduces one character wearing a sign that reads "Happiness" and another, standing next to her, carrying a sign reading "Un." All this happens as the Skeinster allows a mother to unravel her life and her daughter's. In this Ovidianlike gem, Parks blends a nursery tale with a mythological horror story - a take-off 
on the spinning Fates. By the way, these "Mythical Murderesses" appear in "Live Free or Die," "holding hands like in Red Rover." ${ }^{60}$ Clearly, Parks has brilliantly pushed the genre(s) envelope as far as it can go.

Still, 365 bears the stamp of Parks's important and recurring characters, techniques, and topoi. At least half a dozen plays spotlight Abraham Lincoln in whom Parks has an overarching interest. Two of her earlier full-length works - the America Play (1990-1993) and Topdog/Underdog (2003) — turn on a black man named Lincoln, dressed up with a beard and a stovepipe hat, who works in an arcade where customers pay to take a shot at the president, replicating Booth's assassination. But from her vantage point of "radical re-envisioning," Parks interrupts American history in these Lincoln scripts to dislodge the hallowed traditions and emblems associated with the $16^{\text {th }}$ president. In the process, she topples the authority/autonomy of white history in which Lincoln's legacy has been enshrined. Parks's Lincoln is as far removed from the avatar of American history as is his look-alike in the Rozerem (sleeping pills) television commercial showing the president seated at a table along with a larger-than-life beaver enticing insomniac viewers back to the dream world from which these strange bedfellows have been evicted.

In "The Birth of Lincoln," the president's father, accompanied by a Mystic Friend, awaits the birth of his son, attended by a black midwife. Parks realigns American history by making an African American responsible for birthing the author of the Emancipation Proclamation. Challenging the mythos of a log cabinreared Lincoln, the Mystic Friend assures Father Lincoln that his son will lead an extraordinary life to which Lincoln Senior crudely responds, cut "yr Hindu claptrap." Parks mockingly alludes to Lincoln, wrapped in "swaddling clothes," as a Christ figure, and also in "Mr. Lincoln Rose" where she satirically links him to Christ through a pun on "rose" (flower/resurrection). Manipulating white history in "Abraham Lincoln at 89," Parks situates him at a celebration, but being full of pride and mortality, the president is told that it is "an act of self flattery" to have a party when he was not alive to merit it, an ironic indictment of the way white history can manipulate events. Associating this "Mr. Former President" with later war-mongering leaders in “A Promise Made in 1863 Isn't Worth Much These Days," Parks fast-forwards Lincoln's fantasy life to Hollywood where, he claims, "I did not think the war would last this long. None of us did," as bombs go off in the distance. Anachronistically, "a car backfires" when Mrs. Lincoln and Mrs. Keckley, her black dressmaker, talk about the war, which "is female . . . Because it is so tenacious" like Mary Todd Lincoln who, because of her meddling in military and other matters, turned into her husband's nemesis. In "Lincoln at 89," and "Mrs. Keckley \& Mrs. Lincoln," Mary exchanges outfits and/or headdresses with her black dressmaker, underscoring Parks's scathing re-evaluation of the absurd codes of identity/status in Jim Crow America, when blacks could not try on clothing in stores for fear of racially tainting the garment a white person might wear. ${ }^{62}$ Apropos, the 365 play 
for July 11 is provocatively entitled "I Can't Help the Mood I'm In, But Right Now Im Thinking that the Narcissism of White American Knows No Bounds." ${ }^{93}$

Two plays on "Presidents Day Sale" further dislodge Lincoln (and other presidents) from a valorizing white history. In the first, he is one of six presidents who are for sale - including "the greater of the 2 Roosevelts, [and] the 2 Bushes." Each appears in a lineup, repeating his most hallowed line, Lincoln's being "4 score and 7 years ago," which are reduced to sloganizing in Parks's postmodern marketplace. In "The Day After The Presidents Day Sale," the only presidents left for purchase are a "bunch of nobodies"-Quincy Adams, Wilson, Cleveland, Hoover, etc. The customer who selects Garfield claims he will "look great in our courtyard," replacing, no doubt, the racist statue of a black jockey found in white yards with a devalued president. Further exploding presidential sanctity, Parks queers a national mantra, "Washington Slept Here," by implicating the first president in a homoerotic union with a soldier whose form is still visible next to where Washington putatively spent the night. Parks converts Washington's credo (in "The Presidents Day Sale") to double talk: "I cannot tell a lie I cannot tell a lie." "64

Consistent with 365 's debunking traditions (political as well as theatrical) are a series of plays where individuals are turned into numbers or carry signs or sandwich boards conferring identity on them. Parks serves up a jambalaya of farout allegory, Elmer Rice impressionism, and Beckett-like symbolism. Characters in "Sunshine" are labeled 1, 2, 3, 4, 5 while in "9-11" a man and a woman, each in a white suit and on stilts, repeat "Nein" eleven times. In "King's Head," "each person wears a number, [but] folded, not visible. Every so often one of them peeks through a curtain." Yet the numbers are not sequential; they are random just like the lives of the characters who bear them. In a double spoof of national numbers and Hollywood adventure (Indiana Jones or Superman) and Blaxploitation films (Shaft), 365 's "From the Absolutely True Adventures of Afrodite Jackson-Jones" has Wanda X tell Rufus: "My little sister, Shandra, she walked around like a different 1776 historical personage every week: Betsy Ross, Ben Franklin, Crispus Atticus ... the little drummer boy . . the unknown soldier." ${ }^{165}$ In racist America, a black child "walk[s] around" as if in a tomb.

More than twenty plays revel in Parks's exploitation of mimesis (representation) turned in on itself, that is, self-reflexive plays that interrogate what exactly constitutes a script. Trumpeting Parks's theatrical chutzpah, it is little wonder that the Traditionalist in "Beginning, Middle, End" is surrounded and beaten by Riot Police. Having a carload of Derridian fun, Parks self-consciously writes plays about writing plays. This is hardly surprising since, as she says, when she did not have a specific topic before her, she wrote about the act (or anxiety) of creation. There are plays on "First Beginnings," "The Leaving," "Arrival of the End," and "All Good Thing Must Come to an End." She collapses dramatic categories into characters in "The Birth of Tragedy" where Tragedy is cast as a spoiled brat wearing 
a robe and a crown, calling for the death of dignitaries and where the Titlematrix in "Titelmania" is equally draconian. The theatre schedule itself comes in for a postmodern autopsy in "Opening Night," "Between the $1^{\text {st }}$ Rehearsal and the $2^{\text {nd }}$," and "An Intermission" where the words, actions, and spaces between the play are the play. Signaling Parks's own artistic frustration are "Going Through the Motions," "This is Probably Not a Play," and "This is Shit."

In several plays, Parks turns text into body and body into text. In "What Do You See?" a characterless voice declares it would "fill the blank page with body parts. And a list: of the people I'd like to raise from the dead." Another voice undercuts such pretentiousness, retorting: "They'd stink." In "The Script," a palm reader reminds a stooge that an entire play can be staged in his hand, which could be "sliced with an enormous knife." Parts of a body are used as text. In "The Original Motherfucker" Oedipus nonchalantly announces, "I'm just here to fill some gaps about the play: like the writer didn't get around to writing, or what was cut, or what the censors cut." A character is "squeez[ed] into text under Doomsday" in "Book." In "Paper Tomatoes," characters throw "wads of paper" at a Strong Man trying to hold "back his tears," a postmodern reversal of the symbols of rejection (rotten tomatoes) and the medium for written creative work (paper). In "Unfit to Print," a recent bride kills her husband and plans to "get off scott-free and sell my memoirs." In so doing, she uses that forthcoming text to erase the husband's body and replace it with her own and a fame-hungry cop's who, after apprehending her, "turns in his badge and gun, quits his job," because, as the murderous spouse claims, "Yr gonna see me on TV and wish you were me." In "The Amanuensis," the scribe/secretary wants a play on what she writes, and in "Her Amanuensis," a pompous Great Poetess, in the middle of her dictation, orders, "And should, while yr reading, if I should die, chart every aspect of my decomposition. . . . The rigor mortis . . the stench . . My rotting body will be my final text." ${ }^{96}$ Ironically, the last play in the year-long cycle showcases the actual manuscript of 365 as the only performer, hopefully not decomposing.

The most obviously themed 365 plays are the "Father Comes Home from the Wars," scattered into 11 parts with an additional "Mother Comes Home from the Wars," bringing the series to an even dozen. Like other homecoming plays, such as Arthur Miller's All My Sons, David Rabe's Sticks and Bones, or Lanford Wilson's The Fifth of July, the "Father Comes Home" series captures, the mental and moral breakdown of the soldier, the family, and the society that sent him/her off to war. Aiming for "black play" universality, Parks intends no specific war; she claims it could be the "Trojan, Crimean, Spanish Civil, Zulu, or ANC," though numerous allusions to Vietnam and Iraq smolder in these plays. In Part 7, Father is back from "jungle combat" and teaches his children to use "chopsticks;" Iraq, undoubtedly, was a catalyst for these plays since the U.S. declared war in March 2003 while Parks was in media res with 365. The "Father" plays range from 
the mock heroic to existential farce to a Hindu ritual. The result is grimly funny, chilling, grotesque, a terrifying roux of Artaud, Beckett, Ionesco, Albee. Parks's experimental streak in "Father" begins with simultaneous monologues by Mother and Father in Part 1 and ends with a dizzying exchange/blur of dialogue between returning soldiers and wives emerging from the audience in Part 11.

Although no deep psychological characterizations fuel the "Father" plays, Parks's explosive language and highly symbolic stage directions are claymore mines to catch the conscience of audiences nationwide. Father's homecoming is neither anticipated nor, in many plays, welcomed. In "Father Comes Home, Part 1 " "[u]nopened envelopes" and later the abandoned house send strong stay-away messages to the returning husband. In Part 9, the children are "Grown up and moved away." In Part 2, Father enters as a family portrait is being done, with his surrogate comfortably in place, "but they [all] cringe and shrink from his touch." In Part 6, "He doesn't come home at all." When he does in Part 3, Father has no goal except to watch "game shows" on television as "soldiers in the doorway make loud war sounds, ${ }^{, 68}$ symbolizing the inescapable war he brought home with him. An Atlanta company punctured the idealized American family scenario in this Father play: "Mother bakes while her adorable and well-behaved son and daughter look on lovingly. Father returns home from war in 'Hi, Honey, I'm home' style, [but] his tone becomes rough and unsuited to his pre-war world. [Director] Westdahl's chilling interpretation of this piece contrasts with iconic images of the American home with those of war. The war literally invades the "American Dream." ${ }^{\prime 69}$

These "Father" plays dramatize the effects of a post-traumatic stress syndrome crippling American society. Returning veterans are described as "forgetful, passive, paranoid, sad, weak, infirm, angry" in Part 9. He admits from the start that the "furniture was purchased with the blood of some people I used to know-and some blood of the people I need to kill." In Part 7, Father "smacks [a] Kid upside the head" for not using chopsticks properly. In Parks's domestic horror story of war-infected America, Father's pre-war taste for home cooking has been replaced with a literal "taste for killing"; in Part 6, he wants to eat his animals "with the skin on." Soldier Mom, too, comes home ready to report and to shoot her husband. Tragically, Father's damaged psyche is housed in a mutilated body. In Part 2, “ it is clear he is missing an eye, a leg, an arm." In Part 7, he confesses, "I got a full suit. Some guys just get the jacket or the shoes. Some guys don't got a need for shoes, cause they don't got feet." Reminiscent of Willy Loman's race with the junkyard, a former soldier, the Mechanic, tells another comrade in misery (the Janitor) in Part 9: "Least they didn't put you on the junkpile. That's where they put me. Cause I'd cost them an arm and a leg to fix. So they junked me. After that I was turned to junk. Drugs, you know." Parks's "Father Comes Home” plays anticipate, by only a few quick years, the nightmare bureaucracy and medical horrors amputees face returning from Iraq. In the most scathing play in the series, a character asks in Part 


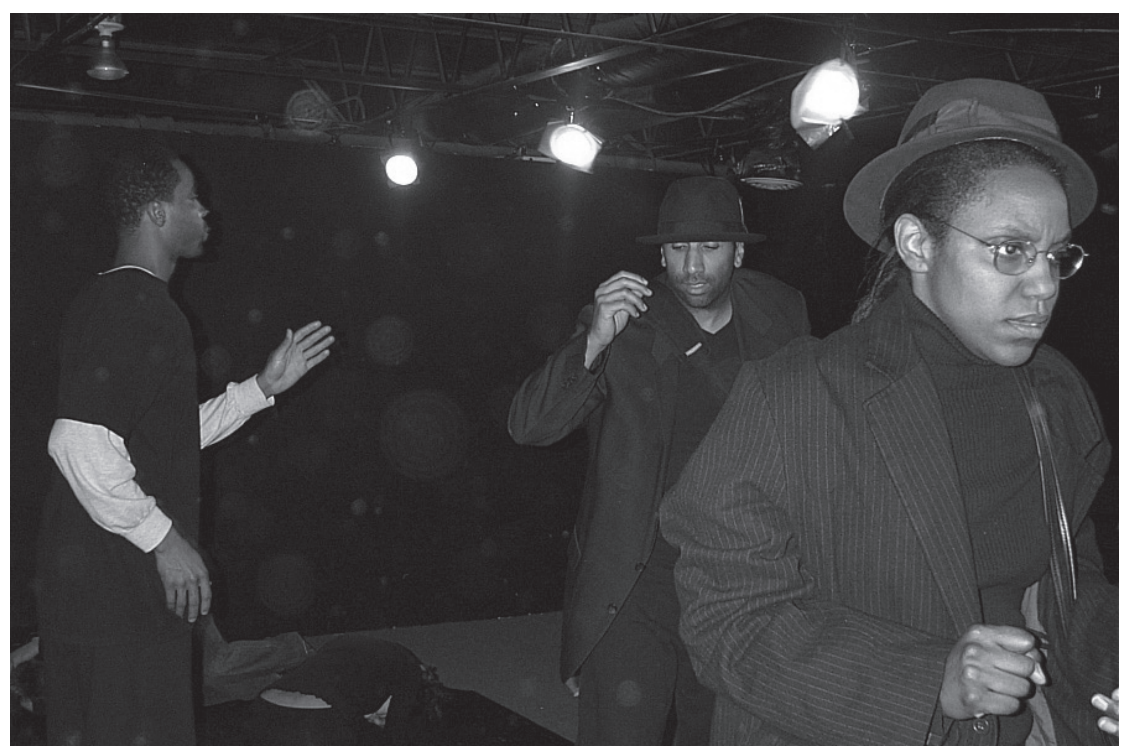

The Company Acting Studio, Atlanta GA: "We Were Civilized Once" 365 Days/365 Plays, February 12-18, 2007.

9, "Why have war at all?" and another responds, "There's money in the clean-up,"70 an answer that should burn a hole in the conscience of corporate America. Images of a monolith like Haliburton, which has profited from Iraqi clean-ups, comes to mind as the ultimate scavenger in the holocaust that 365 chronicles.

Parks and Metzgar have made theatre history by challenging the borders of theatre, even the avant-garde at its most extreme. 365 is, unquestionably, a milestone in American theatre and popular culture. Promulgating radical inclusiveness, 365 erases the entire spectrum of theatre-how it is created, coordinated, financed, marketed, staged, and received. Perhaps at its most productively radical, 365 assaults the hegemonies by which theatre has been controlled. No wealthy producers or Big Daddy directors determine where and how, or even if, 365 can be staged. Making 365 freely and readily available to any performance group, Parks and Metzgar have used their enormous influence (as Pulitzer-prize winning playwright and leading producer) to reclaim the popular/ritualistic heritage from which theatre emerged. In relinquishing authorial prerogatives over performance(s) of the script, Parks and Metzgar have also succeeded in forming a new theatre ideology that empowers the creative spirit of nation. 365 is filled with promise, direction, opportunity, and questions about the performance and the role of theatre in American (even world) culture.

But 365 also raises throbbing questions. "As a playwright I try to do many things," Parks declared, "explore the form, ask questions, make a good show, tell a good story, ask more questions, take nothing for granted." ${ }^{11}$ One of the most significant questions that 365 raises, one that has long-range implications, concerns 
its future production history. What will, can, or should constitute a production of 365 beyond the National Festival of 2006/2007? While the August Wilson Theatre will stage a marathon production of all of 365 in 2007, it seems prudent to speculate that only the most heavily subsidized theatres would ever have the resources - actors and audiences - to perform the entire cycle in the future and that such productions might be infrequent. The time alone required for a production of 365 is formidable. In 2006, the Public Theater did just a reading of the 365 plays, and had to divide them into four sessions, reading the first five months (from August 17 to 18) and the "second half" of 365 on September 28-29. So, staging, or even reading, all the 365 plays is far from feasible.

But then, would it be permissible, possible, or even desirable to select a week or two at random or could 52 plays (one from each week, say) be stitched together to form a play, or might a theatre pick and choose eight or ten of the longest/most "contemporary" plays and turn them into a "fuller" evening of performance? (Of course Parks, like Tennessee Williams, might very well expand one of more of the 365 plays into a full-length work down the seasons). Or might a director stage a linked group, such as "Father Comes Home" or "House of Jones," as 365 ? Or would other selections based on characters - women (mothers, wives, daughters) — or themes (race, music, prisons, urban culture, apocalyptic punishments) - a priori still be considered 365 ? These questions do not unsettle the 365 spirit, but they do speak to its continuing impact in the theatre and on American culture.

Ultimately, 365 might best be realized as cyberspace, or digital theatre, a theatre of virtual performance(s). Seeing the 365 cycle of plays as analogues to screens in indeterminately linked web sites makes sense. Each 365 play, or group of plays, might be envisioned as a link connecting readers/audiences to yet another link, whether it be a day's or a week's or a month's worth of performances by theatres/performance groups/independent artists nationwide. Web space becomes performance space. As the 800 or more theatres and groups that have performed the plays demonstrate, they are organic, fluid, and fascinating, deserving to be restaged, re-interpreted as any theatre or troupe will determine. Seeing the future of 365 as cyberspace performance is also highly compatible with the practice of many theatres/groups that already have recorded productions online of their individual weeks. Moreover, considering 365 as cybertheatre implies that while theatres/ individuals are now disallowed from mounting productions of random weeks, online audiences would be empowered, in effect, to see variations of the entire cycle, a day, a week, or a month at a time and in any order as theatres, groups, and individual artists chose to display and share their performances on and with Internet audiences. In this respect, 365 Days/365 Plays has the very real possibility of living up to one of Parks's key definitions of a black play_- "It embraces the infinite." 


\section{Notes}

1. Suzan-Lori Parks, 365 Plays/365 Days (New York: TCG, 2006) ii.

2. Qtd. in Christopher Reynolds, "365 Plays, One Day at a Time: Suzan-Lori Parks Spent a Year Writing a Play Per Day. Now They're Being Staged," Los Angeles Times, 17 Nov. 2006: E ("Calendar") 3.

3. Hilton Als, "The Show Woman," The New Yorker, 30 Oct. 2006: 73.

4. Joseph Roach, "An Interview with Suzan-Lori Parks and Bonnie Metzgar." Trumball College, Yale Univ., 14 Nov. 2006, http://www.yale.edu/wpp.

5. Damaso Reyes, "Public Theatre Debuts Suzan-Lori Parks's ‘365 Days/365 Plays,”” New York Amsterdam News, 30 Nov. 2006: 20, http://www.amsterdamnews.org/.

6. Ken Bullock, "The Theater: Two East Bay Troupes Join 365 Days/365 Plays," Berkeley Daily Planet, 21 Nov. 2006, http://www.berkeleydailyplanet.com.

7. Tony Adler, "Parks's 365" So How's Your Year So Far?" Chicago Tribune, 12 Jan. 2007, http://www.chicagotribune.com/. html.

8. Shannon Richey, "Zachery Scott Theater," 28 April 2006 http://www.zachscott.com/365/index.

\section{Als 78 .}

10. Qtd. in Kathryn Walat, "These Are the Days," American Theatre, 23 Nov. 3006: 27.

11. Qtd. in Danielle Mindess, “365 Blog,”30 April 2006, http://www.Mindess@woodruffcenter. org.

12. Chloe Veltman, "The Year of Playing Dangerously: Suzan-Lori Parks is Either Crazy or Brilliant or Both," San Francisco Weekly, 3 Jan. 2007, http://www.sfweekly.com.

13. "Suzan-Lori Parks '85 Comes Home to MHC," 7 Mar. 2007, http://www.mtholy/oke.edu/ offices/commnewsfull.shtml?parta.

14. Randy Gener, "One Nation, Under Suzan-Lori Parks," American Theatre, Apr. 2006: 1011.

15. John Moore, “Curious '365' Stagings Amazing,” Denver Post, 25 Nov. 2006, http://www. denverpost.com/search/ci 4638147.

16. Qtd. in Nelson Pressley, "The Playwrights Full Circle," Washington Post, 12 Nov. 2006.

17. Arthur O. Lovejoy, The Great Chain of Being (New York: Harper and Row, 1965).

18. http://www.365days365plays.com.

19. Qtd. in Mark Blankenship, "A Year-Long Maze of Plays," Variety, 11 Nov. 2006, http://www. variety.com/article/VR1117953711.html.

20. Qtd. in Michelle Mondo, "Project Attracts Local Theatre Group," San Antonio Express-News, 29 Nov. 2006.

21. Roach.

22. Brendan Kiley, "Theater News: 365 Plays," The Stranger [Seattle], 14 Nov. 2006, http://www. thestranger.com/seattle/Content?old $=104386$.

23. Moore.

24. Adler.

25. Denise Garrity and Brandon Hayes, "Goodman Theater Presents Short Plays by Suzan-Lori Parks on May 11 As Part of Looptopic Celebration,”27 May 2007, Press@GoodmanTheater.org.

26. Qtd. in Misha Berson, "Writing a Play-a-Day Explores the Day-to-Day," Seattle Times, 6 Feb. 2007.

27. Qtd. in C. Denby Swanson, "Yoga Drama," Austin Chronicle, 10 Nov. 2006, http://www. austinchronicle.com. 2007.

28. Qtd. in John Holman, "National Parks," Creative Loafing [Atlanta], 28 Dec. 2006-3 Jan.

29. Mark Blankenship, “'365' Theatre Project Unites U.S. Colleges and Universities,” Diverse Issues in Higher Education 24 (Mar. 2007): 23.

30. Reynolds.

31. Alexis Soloski, “The Daily Show," The Village Voice, 20 Nov. 2007, http://www.villagevoice. com/theater/0647,soloski,75082,11.html.

32. Angela Carter. "Drama City: Drama Group Performs Street-Level Playlets," New Haven Register, 19 May 2007, http://www.nhregister.com/.

33. Veltman.

34. Mark Collins, "Lafayette Producer, Acclaimed Playwright Launch 365 Days/365 Plays," Boulder Daily Camera, 12 Nov. 2006.

35. Sadie Dingfelder, "Play as You Go," Washington City Paper, 14 Dec. 2006, http://www. 
washingtoncitypaper.com.

36. Berson.

37. Roach.

38. Qtd. in Reyes.

39. Roach.

40. Gener.

41. Roach.

42. Gener.

43. Qtd. in Wendell Brock, "Getting a Grip on '365 Days," Atlanta Journal Constitution, 8 Dec. 2006: K2.

44. Parks, 365 Plays, 365, 132, 264.

45. Swanson.

46. Qtd. in Carter.

47. Holman.

48. Walat.

49. "Questioning Authority: Rundle on the Art of Dramaturgy," 19 Apr. 2007, http://www. mytholoke.edu/office/commun/news/1319/shtml.

50. 117,310 .

51. Roach.

52. Qtd. in Barbara Cassidy, "The Imperceptible Mutabilities of Suzan-Lori Parks in 365 Plays and as Many Days Across the Whole Kingdom," The Brooklyn Rail, 8 Apr. 2007, http://www.mobklynrail. org $/ 2006 / 11 /$ thea-dialogue.

53. Qtd. in Reyes.

54. Suzan-Lori Parks, "New Black Math" in "A Forum on Black Theatre: What is a Black Play," Theatre Journal, 57 (Oct. 2005): 576-83.

55. Parks, 365 Plays 132, 368.

56. 365 Plays $\mathrm{x}$.

57. 294, 11, 293.

58. Laurel E. Ollstein. E-mail to author, 27 Apr. 2007.

59. Roach.

60. 365 Plays 338, 304.

61. 121, 27, 26.

62. Mark Smith, How Rice is Made: Slavery, Segregation, and the Senses (Chapel Hill: U of North Carolina P, 2006).

63. 365 Plays 251.

64. $127,129,128$.

65. 244,300 .

66. $52,221,117,234,299,307$.

67. 119, 205.

68. $232,119,174,147$.

69. Mindess, "Week 17."

70. 310, 6, 206, 172, 119, 171, 311 .

71. Weekly Program, "Community Theatre Presents," DeKalb, GA, 15 Dec. 2006. 


\section{THE FIELD}

Forum on the 20th Anniversary of the

Journal of Dramatic Theory and Criticism 
